\title{
Assessment of the Impact of Seafarers' Professional Experience on the Perception of Risk Factors from the Perspective of Polish Container Ships Crews Members
}

\author{
Ludmiła Filina-Dawidowicz ${ }^{*}$, Daria Możdrzeń1, Włodzimierz Rosochacki \\ ${ }^{1}$ Faculty of Maritime Technology and Transport, West Pomeranian University of Technology, 41 Piastów Avenue, 71-065 Szczecin, \\ Poland \\ *Corresponding author, e-mail: ludmila.filina@zut.edu.pl
}

Received: 18 March 2020, Accepted: 24 May 2020, Published online: 25 November 2021

\begin{abstract}
Safety of navigation is the important issue especially related to the dynamically developing container shipping. The main purpose of the article is to demonstrate the results of research on the perception of risk factors by seafarers working on container ships in terms of their professional experience. The ranking of risk factors considering their impact on the safety of container shipping has been created. An additional goal of the research was to acquire the knowledge on ships crews members' assessment of the impact of the human factor on the safety of navigation, including factors related to the organization of seafarers' work (systemic aspects) and those directly resulting from the operations carried out on ship. The assessment of risk factors affecting the navigation safety was performed from the perspective of Polish crew members working on container ships. The research was carried out with the use of an empirical study questionnaire. 161 seafarers' opinions were analyzed. On the basis of the created risk factors ranking analysis, it was found that seafarers perceive the human factor, and consider both the systemic and the work-related aspects having the greatest impact on the safety of container shipping. Moreover, the conducted non-parametric Pearson chi-square independence test proved the hypothesis that assessments of the five highest rated risk factors, reviewed by studied young and experienced professional groups of seafarers, didn't differ significantly.
\end{abstract}

Keywords

container shipping, transport safety, risk factors analysis, human factor, seafarers

\section{Introduction}

Today, the development of the global commodity exchange market depends significantly on the conditions of container transport technology (Filina-Dawidowicz and Gajewska, 2018). This is especially noticeable in maritime transport. At the beginning of the second half of the last century, ships carried only several dozen containers on their decks. Over the years, construction technology was improved, creating next generations of container transport vessels (Botter et al., 2018). The current decade is the time of Ultra-Large Container Vessels (ULCV). These are vessels that can transport over 10,000 TEUs (20-foot equivalent units) at the same time. In 2018 more than 450 ships of these kind were in operation. The largest of them have a capacity of over 23,000 TEUs, and their crews have up to 30 members. The introduction of such vessels into service altered the global container transport map (Shenkar and Rosen, 2018).

The operation of each container ship, as in the case of operation of each transport vehicle, is associated with the uncertainty of carrying out the transport service. This state is known as risk. It is important to keep the risk level as low as possible. For this reason, a significant role is attached to activities related to risk management. The typical approach here includes: identification and analysis of risk factors, risk assessment (including estimation of the probability of occurrence of events that may generate negative consequences and their scope), defining actions leading to risk reduction, calculation of selected risk measures (Berg, 2013). Risk assessment enables the safety management process to be implemented.

A formal approach to shipping safety management is represented in the document of the International Maritime Organization - IMO (IMO, 2018). It presents the principles of Formal Safety Assessment (FSA). The basic objective 
of that study is to define "a structured and systematic methodology, aimed at enhancing maritime safety, including protection of life, health, the marine environment and property, by using risk analysis and cost-benefit assessment". The analysis of this document indicates that the identification and assessment of the risks associated with shipping form a significant part of the presented methodology. Risk is defined as "the combination of the frequency and the severity of the consequence" (IMO, 2018). In IMO terms, there are "risks associated with consequences such as injuries and/or fatalities to passengers and crew, environmental impact, damage to the ship or port facilities, or commercial impact". The aforesaid consequences may be the result of a specific unintentional event (accident) causing loss of navigation safety, e.g., collision, fire, loss of stability, etc. It is estimated that for a 19,000 TEU vessel a potential loss of $\$ 1$ billion is possible, if a ship is lost 80 percent laden (Cassidy, 2016).

One of the important activities leading to minimization of risk associated with maritime container transport is the identification and ranking of factors that have a destructive impact on the safety of container shipping. Identifying such factors and assessing their impact is the domain of experts. These include mainly the experienced crews of vessels. From the point of view of container shipping safety management issues, it may also be interesting to understand how the impact of specific risk factors is perceived by young and inexperienced seafarers, who are still free from routine approaches. Improving the awareness of the crews of seagoing vessels in the field of risk assessment at sea may form an important element of shipping safety management.

The objective of the presented article is to investigate the perception of risk factors of crew members of container ships in terms of the duration of their professional experience, as well as to create a ranking of these factors. The appropriate risk factors were identified and the opinions of both young staff and staff already possessing some professional experience were analyzed. Additionally, the article aims to acquire the knowledge on seafarers' assessment of the impact of human factor on the navigation safety, including factors directly related to the activities carried out on ships and those related to the organization of seafarers' work (systemic aspects).

The presented paper uses Polish seafarers' opinion assessment as a case study. It was estimated that in 2018, over 60,000 Polish seafarers were employed on ships sailing under foreign flags (Rzeczpospolita). Some of them serve on container vessels.

\section{Risk factors in container shipping}

One of the main tasks of navigation safety assessment is the effective identification of risk factors that may initiate the process of generating losses (Goerlandt and Montewka, 2015; Hu et al., 2007; Kontovas and Psaraftis, 2009; Soares and Teixeira, 2001; Stróżyna and Abramowicz, 2015; Sun et al., 2018; Wang, 2002). Their identification is used, among others, to study maritime accidents. A comprehensive review of factors influencing shipping accidents was conducted by Hetherington et al (2006). The authors reviewed the literature on safety in such areas as the human error influence, common themes of accidents, and interventions to make shipping safer, paying attention on fatigue, stress, health, teamwork, situation awareness, decision-making, automation, communication, and safety culture. The causes of marine collisions were also analyzed by Chauvin et al. (2013). These causes include: environmental factors (physical environment, technological environment), errors, violations, operators' conditions (adverse mental state, physical/mental limitations, adverse physiological state), personnel factors (inter-ship communication, alcohol), unsafe leadership, organizational influences. The literature points out that maritime accident databases are a valuable source of information for identifying risk factors in shipping (Hetherington et al., 2006). Baker and Seah (2004) presented the results of research covering the causes of maritime accidents based on the databases of the United States, Canada, United Kingdom and Australia. It was proved that the human factor was the cause of $80 \%$ to $85 \%$ of marine accidents (depending on the analyzed database). About $50 \%$ of maritime accidents were directly initiated by human error. For a further $30 \%$, it was found that even when other reasons initiated them, the erroneous behavior of a person in a critical situation led to the fact that the accident could not be avoided or mitigated.

In studies conducted by Oldenburg et al. (2010), Mellbye and Carter (2017) and Jepsen et al. (2015) the subject of occupational risks of seafaring is addressed. The analysis of these works allowed to indicate several important factors affecting the safety of navigation from the human behavior viewpoint. These include: disasters and accident rates, piracy, impaired treatment options of cardiovascular diseases at sea, fatigue, high load of work-related stress, international crews, selection bias, deep-sea and social isolation, limited opportunities for recreation, environmental stressors on board, occupational cancer, communicable diseases etc. 
Other classifications of risk factors affecting shipping safety are also observed. The structures of these classifications are strongly associated with the adopted approach and objective of the respective risk analysis. For example, in paper (Stróżyna and Abramowicz, 2015) that presents the dynamic approach to risk assessment, it is proposed to group the factors into so-called static risk factors, dynamic risk factors, vague risk factors and history-related ship risk factor. Psaraftis et al. (1998) associated the risk factors with type of vessel, its size, age or origin of the shipowner, and analyzed their impact on accident statistics. The division of risk factors into static, meteorological, dynamic and global was proposed by Soares and Teixeira (2001), this paper presents a fuzzy approach to risk assessment in shipping. The issues of risk factors identification in container transport and assessment of their impact on maritime safety were also discussed by Chang et al. (2014). Baldauf et al. (2016) paid attention to the necessity to gain experience and achieve practical skills by ship's crew members and suggested using specially designed simulators that realistically represent complex conditions on-board vessels, following emergency alerts.

Based on the analysis of the above studies, it can be assumed that in relation to container shipping, as in the case of most technical macrosystems, four typical groups of risk factors can be distinguished. These include human, technical, environmental and organizational (systemic) factors (Berg, 2013; Carotenuto et al., 2012; Chauvin et al., 2013; Filina-Dawidowicz et al., 2019; Görçün and Burak, 2015; Trucco et al., 2008; Zeng et al., 2017). Moreover, as a result of available literature analysis it can be concluded that there is a lack of research results presenting assessment of attitudes related to the culture of maritime safety connected with the professional experience of seafarers and it is reasonable to undertake further research related to identification of young and experienced ship's crew members opinion on the risks associated with work at sea.

\section{Research methodology}

The research was carried out within the following stages:

1. Several electronic databases (e.g., Web of Science, Scopus) were reviewed to identify research articles by using such search terms as: shipping, maritime accidents, safety, risk assessment, fatigue, container ships etc. Literature, reports describing container ship accidents and other documents were analyzed. Moreover, the interviews with people working on container ships were conducted.
2. Based on the collected data, the groups of risk factors and their detailed division were determined. The identified risk factors were consulted with staff working on container ships in order to validate the achieved research results.

3. Based on the outcomes of the previous step, a questionnaire was elaborated, which allowed to conduct research and investigate particular factors' influence on container shipping safety. The questions were divided into two parts. Part I was related to the basic data of respondent who fill the survey. Part II contained questions concerning respondents' perception of risk factors in container shipping and possible efficient risk mitigation methods.

4. The data of four risk groups and twenty-four risk factors were collected via questionnaire. The questionnaire was published on 19.09.2017 on the website (PortalMorski.pl) with the consent of its administrator and was available online until 31 December 2017. The survey was addressed to people who were or had been employed on container ships.

5. Statistical analysis of the ratings filled by respondents was carried out. In order to assess the variability of the formulated assessments, their mean values and standard deviations were determined according to the following formulae:

- mean value:

$M R F_{i j}=\frac{\sum_{k=1}^{n} R F_{i j k}}{n}$,

standard deviation:

$$
S D R F_{i j}=\sqrt{\sum_{k=1}^{n}},
$$

where:

- $i$ - number of factor group; human: $i=1$, systemic: $i=2$, technical: $i=3$, environmental: $i=4$, other: $i=5$;

- $j$ - factor number in the group; $j=1,2, \ldots, 6$;

- $M R F_{i j}$ - mean value of the $j^{\text {th }}$ factor of the $i^{\text {th }}$ group;

- $n$ - number of respondents;

- $R K_{i j k}$ - the value of the assessment of the $j^{\text {th }}$ factor of the $i^{\text {th }}$ group by the $k^{\text {th }}$ respondent,

- $S D R F_{i j}$ - standard deviation of the $j^{\text {th }}$ factor assessment of the $j^{\text {th }}$ group.

6. A ranking of risk factors was created taking into account the average values of responses. 
7. For the five highest-rated risk factors, the hypothesis Ho about the lack of dependence of formulated assessments on seafarers' professional experience was formulated and verified.

\section{Results}

Table 1 presents a proposal for grouping risk factors for container shipping that combines approaches presented in the available literature and takes into account the point of view of seafarers serving on container ships. The factors were assigned to four groups, with two of them directly and indirectly related to the influence of a human factor. Namely, we distinguished a group of human factors directly related to the behavior of seafarers on board (hereinafter referred to as human factors) and a group of factors related to aspects of seafarers' work organization, including work organization on the ship, length of contracts, crew size, etc. (hereinafter referred to as systemic factors). The distinguishing between these two groups was necessary for more detailed analysis of the impact of human

Table 1 List of risk factors in container shipping

\begin{tabular}{|c|c|c|}
\hline $\begin{array}{l}\text { Name and } \\
\text { designation } \\
\text { of the risk } \\
\text { factors group }\end{array}$ & Name of the risk factors & $\begin{array}{c}\text { Factor } \\
\text { designation }\end{array}$ \\
\hline $\begin{array}{l}\text { Human } \\
\text { factors } \\
\text { (HF) }\end{array}$ & $\begin{array}{c}\text { Routine and inattention } \\
\text { Non-compliance with procedures } \\
\text { Negligence in service } \\
\text { Drunkenness (alcohol influence) } \\
\text { Piracy } \\
\text { Other }\end{array}$ & $\begin{array}{l}\text { HF_1 } \\
\text { HF_2 } \\
\text { HF_3 } \\
\text { HF_4 } \\
\text { HF_5 } \\
\text { HF_6 }\end{array}$ \\
\hline $\begin{array}{l}\text { Systemic } \\
\text { factors } \\
(\mathrm{SF})\end{array}$ & $\begin{array}{c}\text { Poor training } \\
\text { Insufficient crew size (as a result of } \\
\text { employment reduction) } \\
\text { Imprecise procedures } \\
\text { Overloading with additional duties } \\
\text { Excessive contract duration } \\
\text { Other }\end{array}$ & $\begin{array}{l}\text { SF_1 } \\
\text { SF_2 } \\
\text { SF_3 } \\
\text { SF_4 } \\
\text { SF_5 } \\
\text { SF_6 }\end{array}$ \\
\hline $\begin{array}{l}\text { Technical } \\
\text { factors } \\
(\mathrm{TF})\end{array}$ & $\begin{array}{c}\text { Malfunctions of devices } \\
\text { Material faults } \\
\text { Errors in the design and construction } \\
\text { of the ship } \\
\text { Material degradation (as a result of } \\
\text { fatigue, aging) } \\
\text { Excessive vibration, resonance } \\
\text { Other }\end{array}$ & $\begin{array}{l}\text { TF_1 } \\
\text { TF_2 } \\
\text { TF_3 } \\
\text { TF_4 } \\
\text { TF_5 } \\
\text { TF_6 }\end{array}$ \\
\hline $\begin{array}{l}\text { Environ- } \\
\text { mental } \\
\text { factors } \\
(\mathrm{EF})\end{array}$ & $\begin{array}{c}\text { Extreme waves } \\
\text { Extreme wind phenomena (hurricane, } \\
\text { cyclone) } \\
\text { Poor visibility (in the effect of fog, } \\
\text { precipitation) } \\
\text { Unfavorable currents } \\
\text { Ice phenomena, extreme ambient } \\
\text { temperatures } \\
\text { Other }\end{array}$ & $\begin{array}{l}\mathrm{EF} \text { _1 } \\
\mathrm{EF} \text { _2 } \\
\mathrm{EF} \text { _3 } \\
\mathrm{EF} \text { _4 } \\
\mathrm{EF} \text {-5 } \\
\text { EF_6 }\end{array}$ \\
\hline
\end{tabular}

activities on the safety of container shipping. In addition, technical and environmental risk factors were analyzed.

161 respondents from Poland completed the survey, including young seafarers with work experience at sea of up to 5 years ( $57.8 \%$ of respondents), and crew members with longer professional experience $(42.2 \%)$. The basic statistics information about respondents that filled the survey is summed up and shown in Table 2.

The respondents were asked to indicate their position (function) occupied on ship. Table 2 shows that $43.5 \%$ of the seafarers performed the operational function (they were officers with a degree II/III and mechanics with a grade III/IV). The management functions were performed by $34.2 \%$ of respondents. In turn, $22.4 \%$ of the respondents performed the auxiliary function, they were motorists, ratings, etc. The respondents held various positions and performed different functions on ships gaining their professional experience.

Bearing in mind that one of the research objectives was to compare attitudes in the formulation of assessments related to the navigation safety by young staff and staff already possessing some professional experience, the obtained survey results are presented for young staff sailing for no longer than five years (marked hereinafter as GR1) and for the rest of the respondents (professional staff) sailing for longer than five years (GR2). All respondents are designated as GR3. Such division was introduced because young staff often gain experience during their studies or taking apprenticeships, which allow them to acquire relevant experience after 5 years of work.

Seafarers gain their experience on different types of vessels (Fig. 1). The largest group of surveyed crew members worked or work on panama ships with a capacity of $2500 \div 4000$ TEU and feeder container ships with a capacity of $1000 \div 2500$ TEU ( $22 \%$ and $20 \%$ of respondents respectively). In turn, $13 \%$ of the examined seafarers gained their professional experience on Suezmax ships $(8000 \div 12000$ TEU). Post-suezmax vessels $(12000 \div 14000$ TEU) were selected

Table 2 The basic statistical information about respondents

\begin{tabular}{lcc}
\hline Information type & Division & $\begin{array}{c}\text { Number of } \\
\text { respondents }\end{array}$ \\
\hline Service period & up to 5 & 93 \\
(years) & $5 \div 10$ & 43 \\
& $10 \div 20$ & 16 \\
Position & over 20 & 9 \\
& captain, I officer, I/II mechanic & 55 \\
& II/III officer, III/IV mechanic & 70 \\
& ratings, motormans & 36 \\
\hline
\end{tabular}


only by $8 \%$ of respondents. There was no young staff seafarer working on vessel with a above 18000 TEU. Fig. 1 (a) and (b), present the ships chosen by young and professional staff. The analysis of the data presented in Fig. 1 demonstrates that seafarers sailing for no longer than five years gain experience on smaller container vessels.

In the basic part of the survey, the respondents were asked to provide information on whether they experienced situations of loss of safety during their work on container ships and - in the event of a positive answer - to indicate the type of factors which caused its occurrence. It should be emphasized that it was a multiple choice question. According to respondents' answers, about $47 \%$ of seafarers experienced human factor related incidents during their professional work at sea, followed by technological factor related situations (experienced by $30.6 \%$ of respondents). The environment factor also contributed to loss of safety at sea and was indicated by $13.4 \%$ of all responses. It should be emphasized that the human factor creates the greatest threat and risks in shipping.
The essence of the research was to obtain information on the perception of risk by persons directly exposed to various negative factors that are characteristic for container shipping. To this end, the second part of the survey included five key questions.

The first question was related to the determination of factor groups (human, systemic, technical, environmental, other) ranking considering their impact on the possibility of loss of safety at sea. In order to implement this task, it was proposed to use a five-point quantitative scale, assuming that 1 point will indicate "the least impact" and 5 - "the greatest impact", the respondent could assign the same value to several factors. Four groups of risk factors, specified in Table 1, were assessed. Additionally a group of "other factors" was proposed to cover other factors, which could not be assigned to above-mentioned groups by respondents.

The results analysis (Fig. 2) revealed that the greatest impact is attributed to the group of human risk factors. This group obtained the highest rating on a fivepoint scale, with $58.39 \%$ of all respondents assessing this

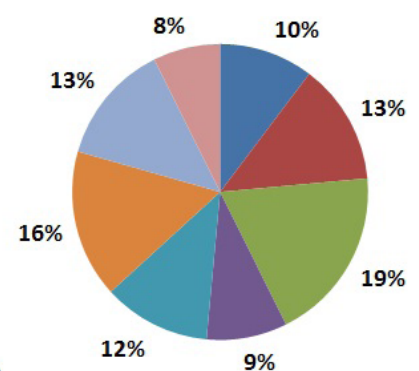

a)

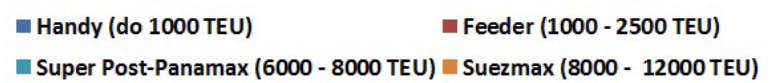

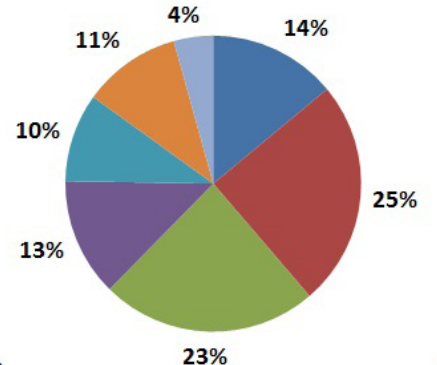

$23 \%$

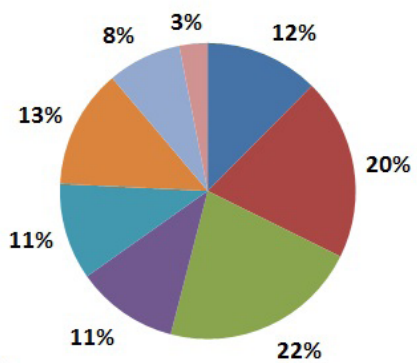

c)

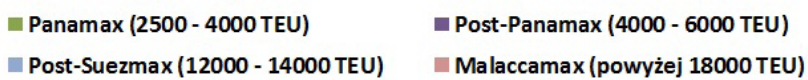

Fig. 1 The type of container ships on which the respondents gained their experience: a) GR1, b) GR2, c) GR3

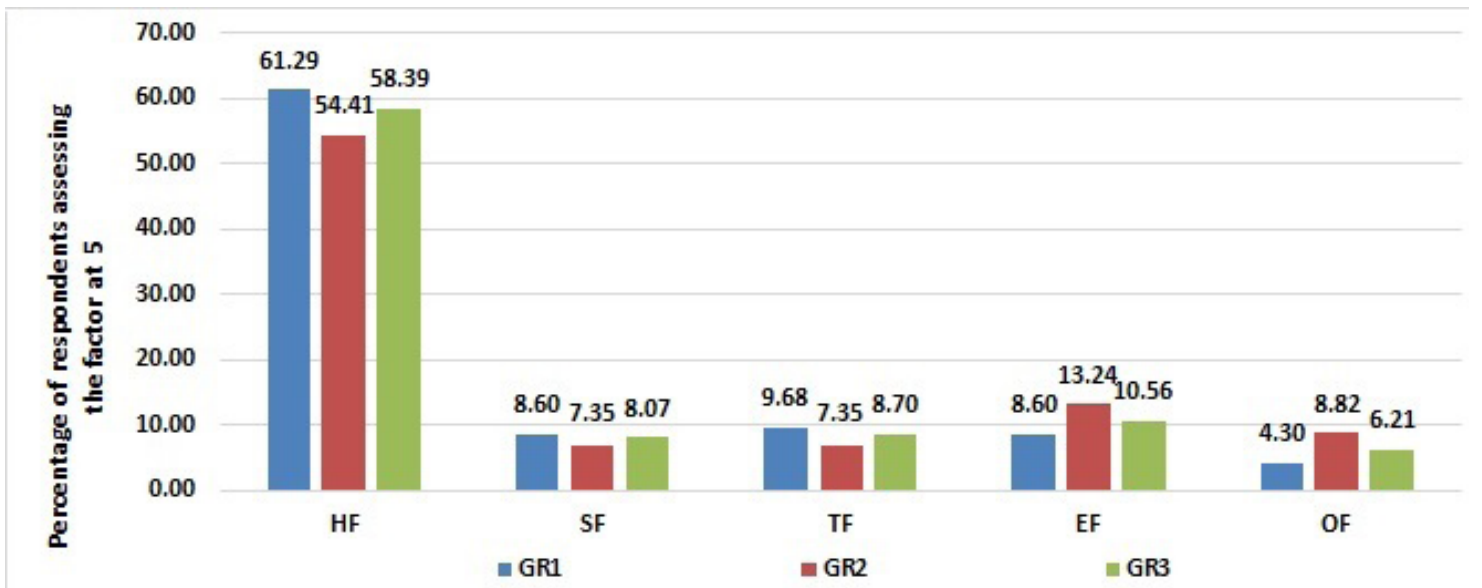

Fig. 2 The percentage of respondents assessing the influence of particular factors at 5 points 
impact with 5 points. Good compatibility of human factors group ratings formulated by both groups of seafarers should be noted (GR1 - 61.29\% of respondents; GR2 - 54.41\%). The ratings analysis shows that almost every third of the respondents did not give 5 points to any of the factors. Systemic factors (GR1 - 8.6\%; GR2 - 7.35\%) and other factors (GR1 - 4.3\%; GR2 - 8.82\%) were considered to be the least important. It needs to be highlighted that experienced seafarers tend to emphasize the importance of environmental risk factors and other risk factors, which is also seen in the relatively lower percentage of 5 ranks assigned to the human factors group.

Fig. 3 presents the ranking of risk factors groups based on the arithmetic mean of the ratings. Seafarers perceive the group of human risk factors as the most important for the navigation safety. Then the groups of technical, environmental, systemic and other factors were placed. Opinions of young and experienced staff differ to a minimum extent only.

The subsequent four questions concerned the assessment of risk factors selected within groups of human, systemic, technical and environmental factors. The respondents were asked to rate individual factors on a 1 to 6 scale (where 1 indicates "the least impact" and 6 "the greatest impact"). In addition, besides the proposed individual factors it was possible to indicate other aspects under the "Other" subheading. The values of arithmetic means and standard deviations calculated for individual risk factors assessed by analyzed groups of seafarers are presented in Table 3 .

The comparison of average rating values formulated by young and experienced seafarers revealed a similar perception of the role of the most significant of the identified risk factors. The results presented in Table 3 gave possibility to develop the ranking of individual risk factors (Fig. 4).
When analyzing the ranking, it should be noted that the first six factors (average means above 4.1 on a six-point scale) are related to human activity and behavior. These are: overloading with additional duties (SF_4), insufficient crew size (SF_2), routine and inattention (HF_1), excessive contract duration (SF_5), non-compliance with procedures (HF_2) and negligence in service (HF_3). When analyzing the ranking, especially in relation to the first two factors, it should be noted that the research covered seafarers employed by various shipowners. This may impact the different perception of these factors. Piracy and other environmental factors were considered to be the least important factors for the safety of navigation.

Based on the results of the ranking, the hypothesis Ho was formulated for the five highest rated factors that formulated assessments put by two studied professional groups of seafarers did not significantly differ. Data for hypothesis verification are included in Table 4.

For the results collected in Table 4, the above hypothesis was verified at the significance level $\alpha=0.01$ using the non-parametric Pearson chi-square independence test. The calculation results are presented in Table 5, where $\chi_{0.01}^{2}$ was determined for $v=(6-1)(2-1)=5$ degrees of freedom.

Taking into consideration that for each of the examined cases the value of chi-square statistics is smaller than the value of $\chi_{0.01}^{2}$, the hypothesis Ho that the formulated assessments of top ranked factors assigned by two studied professional groups of seafarers do not significantly differ should be taken at the significance level $\alpha=0.01$.

At the end of the survey, the respondents were asked to indicate the ways to improve the safety of container shipping. Considering the previously identified risk factors related to human behavior and activities, it was proposed to choose between additional crew training, limitations of

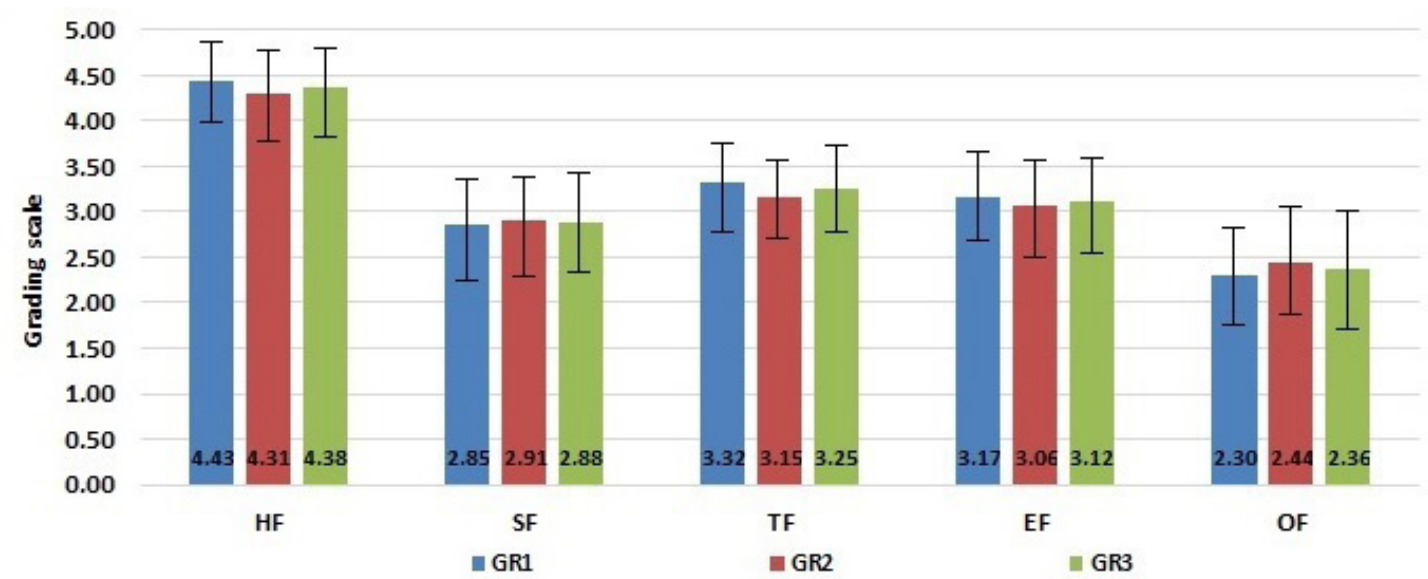

Fig. 3 Arithmetic mean and standard deviation of ratings assigned for particular groups of risk factors by analysed groups of seafarers 
Table 3 Arithmetic means and standard deviations of risk factors assessed by analyzed groups of seafarers

\begin{tabular}{|c|c|c|c|c|c|c|c|c|}
\hline \multirow{2}{*}{$\begin{array}{l}\text { Group } \\
\text { of factors }\end{array}$} & \multirow[t]{2}{*}{ Code } & \multirow[t]{2}{*}{ Factors } & \multicolumn{2}{|c|}{ GR1 } & \multicolumn{2}{|c|}{ GR2 } & \multicolumn{2}{|c|}{ GR3 } \\
\hline & & & $M R F_{i j}$ & $S M R F_{i j}$ & $M R F_{i j}$ & $S M R F_{i j}$ & $M R F_{i j}$ & $S M R F_{i j}$ \\
\hline \multirow{6}{*}{ 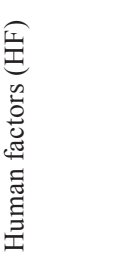 } & HF_1 & Routine and inattention & 4.69 & 1.13 & 4.71 & 1.31 & 4.70 & 1.20 \\
\hline & HF_2 & Non-compliance with procedures & 4.05 & 1.41 & 4.31 & 1.43 & 4.16 & 1.42 \\
\hline & HF_3 & Negligence in service & 4.09 & 1.36 & 4.15 & 1.46 & 4.11 & 1.40 \\
\hline & HF_4 & Drunkenness (alcohol influence) & 3.05 & 1.71 & 3.21 & 1.80 & 3.12 & 1.74 \\
\hline & HF_5 & Piracy & 2.00 & 1.21 & 2.06 & 1.34 & 2.02 & 1.26 \\
\hline & HF_6 & Other & 2.09 & 1.36 & 2.25 & 1.43 & 2.16 & 1.39 \\
\hline \multirow{6}{*}{ 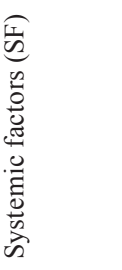 } & SF_1 & Poor training & 3.65 & 1.55 & 3.96 & 1.52 & 3.78 & 1.54 \\
\hline & SF_2 & Insufficient crew size (as a result of employment reduction) & 4.91 & 1.21 & 4.91 & 1.46 & 4.91 & 1.32 \\
\hline & SF_3 & Imprecise procedures & 3.53 & 1.39 & 3.62 & 1.49 & 3.57 & 1.43 \\
\hline & SF_4 & Overloading with additional duties & 5.02 & 1.15 & 5.00 & 1.35 & 5.01 & 1.23 \\
\hline & SF_5 & Excessive contract duration & 4.56 & 1.16 & 4.34 & 1.56 & 4.47 & 1.34 \\
\hline & SF_6 & Other & 2.46 & 1.43 & 2.50 & 1.69 & 2.48 & 1.54 \\
\hline \multirow{6}{*}{ 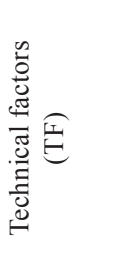 } & TF_1 & Malfunctions of devices & 3.74 & 1.33 & 3.43 & 1.50 & 3.61 & 1.41 \\
\hline & TF_2 & Material faults & 3.15 & 1.29 & 3.12 & 1.63 & 3.14 & 1.44 \\
\hline & TF_3 & Errors in the design and construction of the ship & 2.94 & 1.33 & 3.07 & 1.75 & 2.99 & 1.52 \\
\hline & TF_4 & Material degradation (as a result of fatigue, aging) & 3.81 & 1.26 & 3.84 & 1.48 & 3.82 & 1.36 \\
\hline & TF_5 & Excessive vibration, resonance & 3.23 & 1.26 & 3.19 & 1.48 & 3.21 & 1.35 \\
\hline & TF_6 & Other & 2.33 & 1.32 & 2.46 & 1.57 & 2.39 & 1.43 \\
\hline \multirow{6}{*}{ 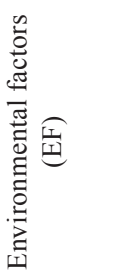 } & EF_1 & Extreme waves & 3.65 & 1.27 & 3.71 & 1.61 & 3.67 & 1.42 \\
\hline & EF_2 & Extreme wind phenomena (hurricane, cyclone) & 4.12 & 1.55 & 4.06 & 1.53 & 4.09 & 1.54 \\
\hline & EF_3 & Poor visibility (in the effect of fog, precipitation) & 3.37 & 1.44 & 3.15 & 1.39 & 3.27 & 1.54 \\
\hline & EF_4 & Unfavourable currents & 2.69 & 1.19 & 2.60 & 1.39 & 2.65 & 1.28 \\
\hline & EF_5 & Ice phenomena, extreme ambient temperatures & 3.05 & 1.31 & 2.76 & 1.46 & 2.93 & 1.38 \\
\hline & EF_6 & Other & 2.05 & 1.10 & 2.25 & 1.46 & 2.14 & 1.26 \\
\hline
\end{tabular}

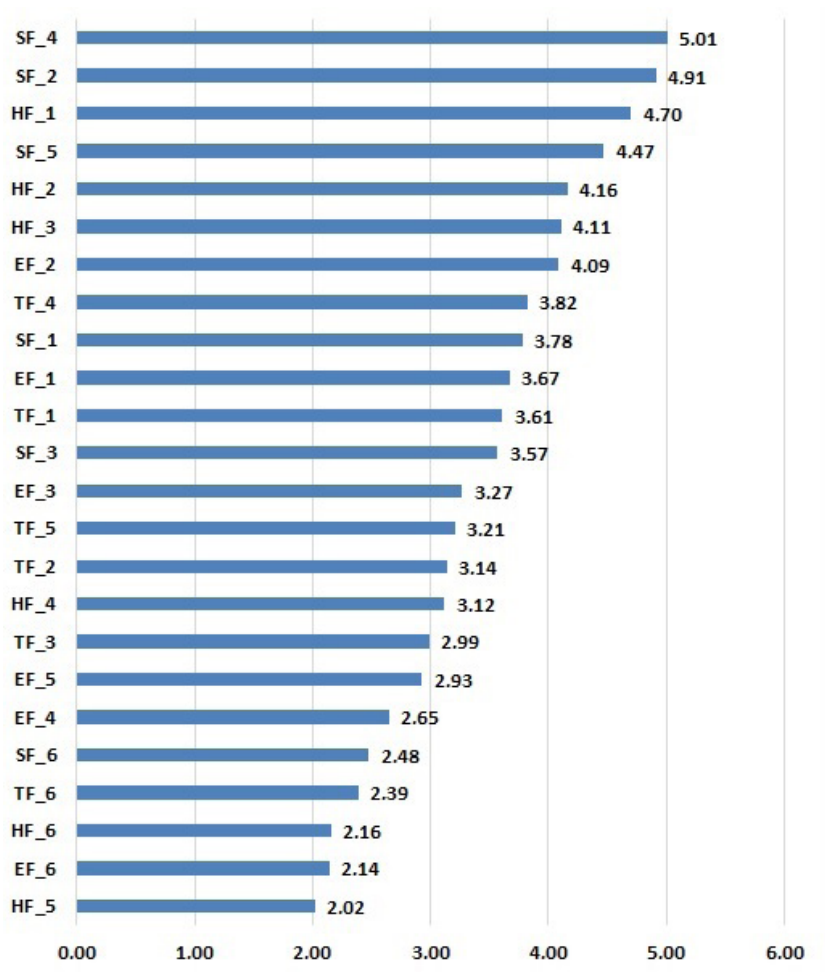

Fig. 4 Ranking of risk factors based on average ratings given by all respondents
Table 4 Number of ratings assigned to individual risk factors by the analyzed groups of seafarers

\begin{tabular}{|c|c|c|c|c|c|}
\hline \multirow{3}{*}{ 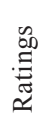 } & \multicolumn{5}{|c|}{ Risk factors } \\
\hline & SF_4 & SF_2 & HF_1 & SF_5 & HF_2 \\
\hline & \multicolumn{5}{|c|}{ Studied professional experience groups of seafarers } \\
\hline
\end{tabular}

\begin{tabular}{ccccccccccc} 
& GR & GR & GR & GR & GR & GR & GR & GR & GR & GR \\
& 1 & 2 & 1 & 2 & 1 & 2 & 1 & 2 & 1 & 2 \\
\hline 1 & 1 & 0 & 2 & 4 & 0 & 2 & 0 & 4 & 3 & 2 \\
2 & 2 & 6 & 2 & 1 & 2 & 3 & 5 & 4 & 10 & 7 \\
3 & 9 & 5 & 8 & 8 & 15 & 6 & 12 & 15 & 18 & 13 \\
4 & 11 & 10 & 16 & 5 & 21 & 14 & 25 & 10 & 23 & 7 \\
5 & 29 & 9 & 27 & 16 & 27 & 20 & 28 & 12 & 23 & 24 \\
6 & 41 & 38 & 38 & 34 & 28 & 23 & 23 & 23 & 16 & 15 \\
\hline
\end{tabular}

access to psychoactive substances, revisions of applicable regulations, providing the ship with modern equipment, reducing the frequency of sailing timetables, shortening of contacts and others. The respondents were able to indicate several options. The obtained results are shown in Fig. 5.

Two of the ways to improve shipping safety got over $60 \%$ of responds. Most seafarers (79.5\%) pointed the contracts shortening as a way to reduce the negative impact 
Table 5 Chi-square statistics and $\chi_{0.01}^{2}$ for the examined factors

\begin{tabular}{|c|c|c|c|c|c|c|c|c|c|}
\hline \multicolumn{10}{|c|}{ Risk factors } \\
\hline \multicolumn{2}{|c|}{ SF_4 } & \multicolumn{2}{|c|}{ SF_2 } & \multicolumn{2}{|c|}{ HF_1 } & \multicolumn{2}{|c|}{ SF_5 } & \multicolumn{2}{|c|}{ HF_2 } \\
\hline$\chi^{2}$ & $\chi_{0.01}^{2}$ & $\chi^{2}$ & $\chi_{0.01}^{2}$ & $\chi^{2}$ & $\chi_{0.01}^{2}$ & $\chi^{2}$ & $\chi_{0.01}^{2}$ & $\chi^{2}$ & $\chi_{0.01}^{2}$ \\
\hline 0.047 & 15.086 & 0.299 & 15.086 & 0.385 & 15.086 & 0.018 & 15.086 & 0.270 & 15.086 \\
\hline
\end{tabular}

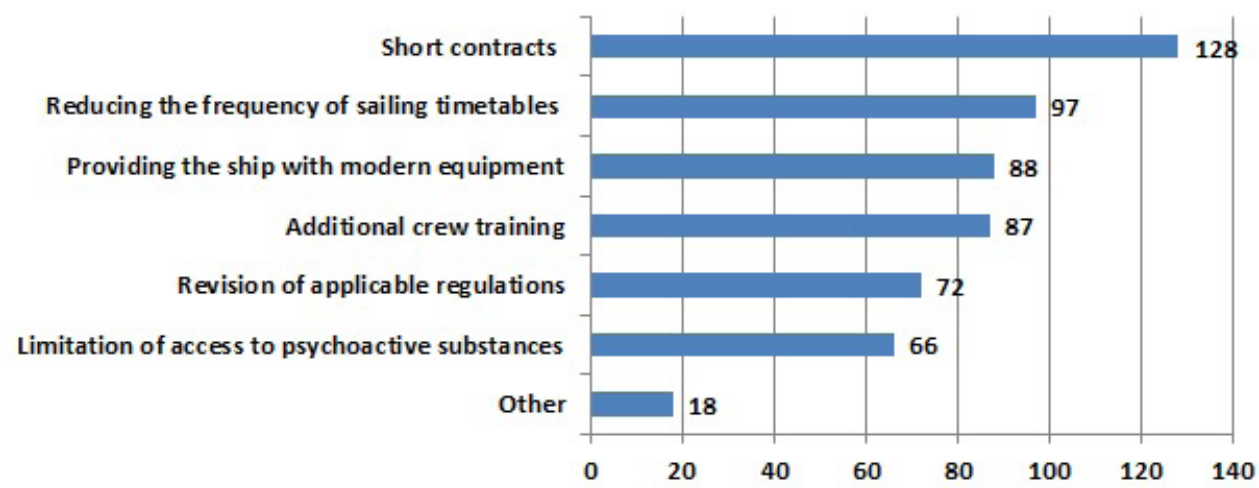

Fig. 5 Preferred ways to improve shipping safety by reducing the impact of human and systemic factors

of human factor on shipping safety. It should be noticed that the "excessive contract duration" was scored only on the fourth place out of all risk factors (Fig. 4). The second indicated solution to improve the shipping safety (indicated by $60.2 \%$ of respondents) may deal with the modification of the timetables and decreasing of ship traffic frequency. It should be highlighted that the results obtained are characteristic for the examined group of people. Answering this question the respondents also had an opportunity to come up with their own preferences concerning the improvement of safety at sea, and they paid attention, among others, to: expanding of crew sizes, introduction of crew mental health tests, regular equipment maintenance, introduction of crew working time supervision systems, or the limitation of recruitment of crews from Asia (including the Philippines).

\section{Conclusions}

Awareness of the importance of the role that man plays in assurance of the container shipping safety is very important. The presented research results indicate that seafarers are well aware of this fact. They perceive the risk factors related to human activity as the most common among other factors affecting the safety of navigation (technology and environment).

The article compares the views of young and experienced seafarers and presents a new outlook on the issue of container shipping safety. It should be emphasized that both young and experienced crew members are well aware of the threats and risks caused by human factor.
In the overall assessment of risk factors, $58.38 \%$ of all respondents rated the frequency (importance of impact) of the human factor at 5 points (using five-point scale), that show a high level of awareness of seafarers concerning the possible impact of this risk factor on shipping safety. Nevertheless, with a more detailed analysis of individual risk factors groups, it was noted that seafarers had indicated the systemic factors as the most significant risk factors, including overloading with additional duties and insufficient crew size on board (as the result of employment reduction). These assessments underline the importance of activities of people working on land in developing the procedures and conditions for seafarers' contracts, which also affect their behavior when working at sea. The results of the present research may contribute to increased awareness of people working on ships and those on land, providing navigation safety.

The direction of our further research will be related to the comparing of the Polish seafarers viewpoint on safety issues with the opinions of container ship crews from other countries. In addition, it will be reasonable to examine the crews perception of threats and risks depending on the geographical navigation area.

\section{Acknowledgement}

The authors wish to thank the administrator of PortalMorski.pl website for sharing the online questionnaire. 


\section{References}

Baldauf, M., Schröder-Hinrichs, J.-U., Kataria, A., Benedict, K., Tuschling, G. (2016) "Multidimensional simulation in team training for safety and security in maritime transportation", Journal of Transportation Safety \& Security, 8(3), pp. 197-213.

https://doi.org/10.1080/19439962.2014.996932

Baker, C. C., Seah, A. K. (2004) "Maritime Accidents and Human Performance: the Statistical Trail", In: MARTECH 2004, Singapore, Republic of Singapore, pp. 225-239.

Berg, H. P. (2013) "Human Factors and Safety Culture in Maritime Safety (revised)", TransNav, the International Journal on Marine Navigation and Safety of Sea Transportation, 7(3), pp. 343-352. https://doi.org/10.12716/1001.07.03.04

Botter, R. C., Santos, T. A., Guedes Soares, C. (2018) "Characterizing container ship traffic along the Portuguese coast using big data", In: Guedes Soares C., Santos T. A. (eds.) Progress in Maritime Technology and Engineering, CRC Press, London, UK.

Carotenuto, A., Molino, I., Fasanaro, A. M., Amenta, F. (2012) "Psychological stress in seafarers: a review", International Maritime Health, 63(4), pp. 188-194.

Cassidy, W. B. (2016) "Mega-ships bring mega-risks, former ship catains tell TPM", Journal of Commerce Online, [online] Mar 02, 2016. Available at: https:/www.joc.com/maritimenews/container-lines/mega-ships-bring-mega-risks-former-shipcaptains-tell-tpm_20160302.html [Accessed: 07 February 2020]

Chang, C.-H., Xu, J., Song, D.-P. (2014) "An analysis of safety and security risks in container shipping operations: A case study of Taiwan", Safety Science, 63, pp. 168-178. https://doi.org/10.1016/j.ssci.2013.11.008

Chauvin, C., Lardjane, S., Morel, G., Clostermann, J.-P., Langard, B. (2013) "Human and organizational factors in maritime accidents: Analysis of collisions at sea using the HFACS", Accident Analysis \& Prevention, 59, pp. 26-37. https://doi.org/10.1016/j.aap.2013.05.006

Filina-Dawidowicz, L., Gajewska, T. (2018) "Customer Satisfaction in the Field of Comprehensive Service of Refrigerated Containers in Seaports", Periodica Polytechnica Transportation Engineering, 46(3), pp. 151-157. https://doi.org/10.3311/pptr.10824

Filina-Dawidowicz, L., Możdrzeń, D., Rosochacki, W. (2019) "Container Shipping Safety: Young Sailors Viewpoint", In: Transport Means 2019: Sustainability: Research and Solutions, Proceedings of $23^{\text {rd }}$ International Scientific Conference, Part I, Kaunas University of Technology, Kaunas, Lithuania, pp. 206-211.

Goerlandt, F., Montewka, J. (2015) "Maritime transportation risk analysis: Review and analysis in light of some foundational issues", Reliability Engineering \& System Safety, 138, pp. 115-134. https://doi.org/10.1016/j.ress.2015.01.025

Görçün, Ö. F., Burak, S. Z. (2015) "Formal Safety Assessment for Ship Traffic in the Istanbul Straits", Procedia - Social and Behavioral Sciences, 207, pp. 252-261. https://doi.org/10.1016/j.sbspro.2015.10.094

Hetherington, C., Flin, R., Mearns, K. (2006) "Safety in shipping: The human element", Journal of Safety Research, 37(4), pp. 401-411. https://doi.org/10.1016/j.jsr.2006.04.007
Hu, S., Fang, Q., Xia, H., Xi, Y. (2007) "Formal safety assessment based on relative risks model in ship navigation", Reliability Engineering \& System Safety, 92(3), pp. 369-377. https://doi.org/10.1016/j.ress.2006.04.011

International Maritime Organization (IMO) (2018) "Revised Guidelines for Formal Safety Assessment (FSA) for Use in the IMO Rule-making Process", [pdf] International Maritime Organization, London, UK, Rep. MSC-MEPC.2/Circ.12/Rev.2, Available at: https://wwwcdn. imo.org/localresources/en/OurWork/HumanElement/Documents/ MSC-MEPC.2-Circ.12-Rev.2\%20-\%20Revised\%20Guidelines\%20 For $\% 20$ Formal $\% 20$ Safety $\% 20$ Assessment $\% 20$ (Fsa)For $\% 20$ Use $\% 20 I n \% 20$ The $\% 20$ Imo\%20Rule-Making\%20Proces...\%20 (Secretariat).pdf [Accessed: 15 February 2020]

Jepsen, J. R., Zhao, Z., van Leeuwen, W.M.A. (2015) "Seafarer fatigue: a review of risk factors, consequences for seafarers' health and safety and options for mitigation", International Maritime Health, 66(2), pp. 106-117. https://doi.org/10.5603/imh.2015.0024

Kontovas, Ch. A., Psaraftis, H .N. (2009) "Formal Safety Assessment: A Critical Review", Marine Technology and SNAME News, 46(1), pp. 45-59.

https://doi.org/10.5957/mtsn.2009.46.1.45

Mellbye, A., Carter, T. (2017) "Seafarers' depression and suicide", International Maritime Health, 68(2), pp. 108-114. https://doi.org/10.5603/IMH.2017.0020

Oldenburg, M., Baur, X., Schlaich, C. (2010) "Occupational Risks and Challenges of Seafaring", Journal of Occupational Health, 52(5), pp. 249-256. https://doi.org/10.1539/joh.K10004

PortalMorski.pl "Portal Informacyjny ISSN 2545-0735" (Information portal ISSN 2545-0735), [online] Available at: http://www. portalmorski.pl [Accessed: 31 December 2017] (in Poland)

Psaraftis, H. N., Panagakos, G., Desypris, N., Ventikos, N. (1998) "An analysis of maritime transportation risk factors", In: ISOPE-1998 Conference, Montreal, Canada, Paper No. ISOPE-98-HKP-02.

Rzeczpospolita "Opodatkowanie marynarzy pracujących u zagranicznych armatorów - fakty i mity" (Taxation of seafarers working for foreign shipowners - facts and myths), [online] Available at: https://www.rp.pl/podatki/art9569031opodatkowanie-marynarzy-pracujacych-u-zagranicznycharmatorow-fakty-i-mity [Accessed: 22 August 2019] (in Poland)

Shenkar, N., Rosen, D. (2018) "How has the invention of the shipping container influenced marine bioinvasion?", Management of Biological Invasions, 9(3), pp. 187-194. https://doi.org/10.3391/mbi.2018.9.3.02

Soares, C. G., Teixeira, A. P. (2001) "Risk assessment in maritime transportation", Reliability Engineering \& System Safety, 74(3), pp. 299-309. https://doi.org/10.1016/S0951-8320(01)00104-1

Stróżyna, M., Abramowicz, W. (2015) "A Dynamic Risk Assessment for Decision Support Systems in the Maritime Domain", Studia Ekonomiczne. Zeszyty Naukowe Uniwersytetu Ekonomicznego w Katowicach, 243, pp. 297-306. 
Sun, D., Jia, Y., Yang, Y., Li, H., Zhao, L. (2018) "Fuzzy-Bayesiannetwork-based Safety Risk Analysis in Railway Passenger Transport", Periodica Polytechnica Transportation Engineering, 46(3), pp. 135-141. https://doi.org/10.3311/pptr.11489

Trucco, P., Cagno, E., Ruggeri, F., Grande, O. (2008) "A Bayesian Belief Network modelling of organisational factors in risk analysis: A case study in maritime transportation", Reliability Engineering and System Safety, 93(6), pp. 845-856.

https://doi.org/10.1016/j.ress.2007.03.035
Wang, J. (2002) "Offshore safety case approach and formal safety assessment of ships", Journal of Safety Research, 33(1), pp. 81-115. https://doi.org/10.1016/s0022-4375(02)00005-1

Zeng, Q., Yang, L., Zhang, Q. (2017) "Modeling the sailing risk of RoPax Ships With Bayesian Network", Transport, 32(4), pp. 340-347. https://doi.org/10.3846/16484142.2014.943806 